\title{
PENERAPAN PEMBELAJARAN KOOPERATIF TEAM ACCELERATED INSTRUCTION (TAI) UNTUK MENINGKATKAN MOTIVASI DAN HASIL BELAJAR SISWA
}

\author{
Mutia \\ Sekolah Tinggi Agama Islam Negeri (STAIN) Curup, Curup, Bengkulu \\ mutianasir24@gmail.com
}

\begin{abstract}
Abstrak
Penelitian ini bertujuan untuk mengetahui bagaimana penerapan model pembelajaran kooperatif tipe Team Accelerated Instruction (TAI) untuk meningkatkan memotivasi dan hasil belajar siswa. Penelitian ini merupakan penelitian tindakan kelas dengan tiga siklus, masing-masing siklus terdiri dari empat tahap yaitu perencanaan, tindakan, observasi, dan refleksi. Penelitian ini dilaksanakan pada mata pelajaran Matematika di kelas VIII-3 SMP Negeri 14 Kota Bengkulu yang berjumlah 37 orang terdiri dari 17 lakilaki dan 20 perempuan. Dari hasil analisis angket siswa, tingkat motivasi siswa dari siklus I hingga siklus III mengalami peningkatan. Pada siklus I sikap positif siswa terhadap pembelajaran TAI yang dapat meningkatkan motivasi siswa adalah sebesar 78,38\%, pada siklus II meningkat menjadi 83,78\%, dan siklus III meningkat hingga mencapai 94,59\%. Peningkatan ini diikuti dengan aktivitas siswa. Hasil observasi menunjukkan aktivitas siswa pada siklus I berada pada kriteria kurang dengan skor rata-rata 15, siklus II meningkat pada kriteria cukup dengan skor rata-rata 22,5 dan siklus III mencapai kriteria baik dengan skor rata-rata 27. Sedangkan nilai rata-rata akhir individu siswa meningkat setiap siklus. Pada siklus I sebesar 56,44, pada siklus II sebesar 72,22, dan pada siklus III sebesar 84,79. Ketuntasan belajar klasikal siklus I sebesar 27,02\%, siklus II mencapai 67,57\% dan siklus III sebesar $91,89 \%$ yang telah tercapai sesuai dengan kriteria yang ditetapkan sebelumnya yaitu minimal mencapai $80 \%$.
\end{abstract}

Kata kunci: Team Accelerated Instruction, Pembelajaran Matematika, Motivasi, Hasil Belajar

\begin{abstract}
This research aims to determine how to implement Team Accelerated Instruction (TAI) of cooperative learning model to increase student motivation and student learning outcomes. The current research is a classroom action research with three cycles, each cycle consisting of four phases: planning, action, observation, and reflection. The research was conducted in mathematic course for class VIII-3 SMPN 14 Bengkulu with 37 students consisting of 17 boys and 20 female. From the analysis of student questionnaire, the motivation level of students from the first cycle to the third cycle has increased. In the first cycle, students a positive attitude towards learning TAI to improve student motivation is equal to $78.38 \%$, on the second cycle increased to $83.78 \%$, and the third cycle increased to 94.59\%. This increase was followed by student activity. Observations indicate activity of students in the first cycle is at less criteria with an average score of 15 , the second cycle increased in sufficient criteria with an
\end{abstract}


Mutia, M. (2016). PENERAPAN PEMBELAJARAN KOOPERATIF TEAM ACCELERATED INSTRUCTION (TAI) UNTUK MENINGKATKAN MOTIVASI DAN HASIL BELAJAR SISWA.JURNAL TATSQIF, 14(2). Retrieved from http://ejurnal.iainmataram.ac.id/index.php/tatsqif/article/view/1023

average score of 22.5 and the third cycle achieve both criteria with an average score of 27 . While the average value of the end of individual students increases every cycle. In the first cycle of 56.44, the second cycle of 72.22 , and the third cycle of 84.79 . Ccompleteness of classical study in the first cycle of $27.02 \%$, cycle II reached $67.57 \%$ and $91.89 \%$ for the third cycle that has been achieved based on the criteria established in advance is at least $80 \%$.

Keywords: Team Accelerated Instruction, Mathematics Learning, Motivation, Learning Outcomes

\section{PENDAHULUAN}

Pendidikan merupakan suatu kebutuhan yang harus dipenuhi dalam kehidupan bermasyarakat, berbangsa, dan bertanah air. Kemajuan suatu bangsa ditentukan oleh kreativitas pendidikan bangsa itu sendiri dengan memanfaatkan sumber daya manusia yang dimiliki yaitu kemampuan dan pemikiran yang sistematis, logis, dan kritis serta berkompetisi secara sehat. Adanya tuntutan pembenahan bagi dunia pendidikan untuk mencerdaskan kehidupan bangsa dalam meningkatkan harkat dan martabat bangsa Indonesia, mengharuskan semua pihak terkait untuk melaksanakan perannya dalam peningkatan mutu pendidikan.

Pendidikan matematika mempunyai potensi besar untuk memainkan peran strategis dalam menyiapkan Sumber Daya Manusia yang berkualitas dan mampu bersaing. Matematika merupakan salah satu komponen dari serangkaian mata pelajaran yang mempunyai peranan penting dalam pendidikan dan mendukung perkembangan ilmu pengetahuan dan teknologi. Tidak mengherankan jika pelajaran matematika dalam pelaksanaan pendidikan diberikan kepada semua jenjang pendidikan, mulai dari tingkat Sekolah Dasar hingga ke Perguruan Tinggi.

Berdasarkan studi awal peneliti, sampai saat ini pembelajaran matematika bagi siswa-siswa di tingkat dasar maupun tingkat menengah masih dipandang sebagai pelajaran yang sulit sehingga matematika kurang diminati bahkan tidak disenangi sama sekali oleh siswa, menakutkan, dan membosankan oleh sebagian besar siswa. Siswa sering menganggap 
Mutia, M. (2016). PENERAPAN PEMBELAJARAN KOOPERATIF TEAM ACCELERATED INSTRUCTION (TAI) UNTUK MENINGKATKAN MOTIVASI DAN HASIL BELAJAR SISWA.JURNAL TATSQIF, 14(2). Retrieved from http://ejurnal.iainmataram.ac.id/index.php/tatsqif/article/view/1023

pelajaran matematika sebagai momok bagi mereka dan guru matematika pun menyadari akan hal itu. Akibatnya, prestasi belajar yang dicapai siswa kurang memuaskan.

Berdasarkan nilai rata-rata akademik yang diperoleh siswa di sebagian besar sekolah masih jauh lebih rendah dari pada nilai-nilai mata pelajaran lain. Hal ini dapat terlihat dari nilai rapot siswa yang menunjukkan keseluruhan nilai siswa untuk semua mata pelajaran dan dibandingkan dengan perolehan nilai matematika yang dicapai belum sesuai dengan yang diharapkan. Seperti yang terjadi di SMP Negeri 14 Kota Bengkulu kelas VIII, berdasarkan informasi yang didapatkan langsung dari guru matematika melalui hasil belajar semester ganjil kelas VIII SMP Negeri 14 Kota Bengkulu tahun ajaran 2010/2011, secara keseluruhan nilai matematika yang diperoleh siswa belum mencapai Kriteria Ketuntasan Minimal (KKM) pelajaran matematika yaitu 65. Nilai ketuntasan yang dicapai hanya diperoleh di beberapa kelas saja yaitu kelas VIII-1 dan VIII-2 sedangkan di beberapa kelas lainnya seperti di kelas VIII-3-VIII-6 memiliki nilai yang beragam, ada yang mencapai nilai KKM dan ada juga yang belum mencapai KKM. Nilai yang diperoleh ini menyebabkan rasa ketidakpuasan guru terhadap hasil belajar siswa. Guru matematika menyatakan keluhan tentang hasil belajar tersebut karena jika dibandingkan dengan sekolah tingkat menengah pertama lainnya, Kriteria Ketuntasan Minimal (KKM) di SMP Negeri 14 ini dapat dikatakan tergolong rendah.

Rendahnya atau belum tercapainya hasil belajar matematika siswa tersebut disebabkan karena banyak faktor. Salah satunya disebabkan karena kurangnya motivasi dan minat belajar siswa dalam proses pembelajaran di kelas. Seperti yang dikemukakan oleh para ahli dalam Hamalik bahwa tingkah laku manusia didorong oleh motif-motif tertentu dan perbuatan belajar akan berhasil apabila didasarkan pada motivasi yang ada pada murid (Hamalik, 2009). 
Mutia, M. (2016). PENERAPAN PEMBELAJARAN KOOPERATIF TEAM ACCELERATED INSTRUCTION (TAI) UNTUK MENINGKATKAN MOTIVASI DAN HASIL BELAJAR SISWA.JURNAL TATSQIF, 14(2). Retrieved from http://ejurnal.iainmataram.ac.id/index.php/tatsqif/article/view/1023

Motivasi dan minat siswa dalam belajar dapat dilihat dari sikap belajar siswa selama di kelas. Berdasarkan wawancara dengan salah satu guru matematika tersebut, mengungkapkan bahwa keadaan yang sering menunjukkan kurangnya motivasi belajar siswa saat kegiatan pembelajaran matematika di kelas antara lain perhatian siswa yang kurang dalam memperhatikan pelajaran karena penyampaian materi yang kurang menarik dan membosankan bagi siswa, mereka lebih banyak melakukan kegiatan yang tidak menunjang proses pembelajaran seperti mengganggu temannya yang sedang memperhatikan penjelasan guru. Terkadang juga siswa yang sudah merasa mampu memahami materi yang disampaikan oleh guru mengalihkan perhatiannya dengan hal-hal yang dapat membuat keadaan kelas menjadi tidak kondusif seperti mengobrol dengan teman sebangkunya. Sebaliknya, ada juga sebagian siswa yang cuek dan diam tanpa berani bertanya karena masih mengalami kesulitan menerima pengetahuan yang disampaikan oleh guru sehingga takut bertanya karena takut dimarah atau dihukum yang pada akhirnya menyebabkan keaktifan siswa dalam pembelajaran masih belum nampak dan belum termotivasi untuk bertanya hal-hal yang belum dimengerti. Melihat kondisi siswa dalam proses pembelajaran yang terjadi di kelas VIII SMP Negeri 14 tersebut, guru sebagai tenaga pendidik hendaknya dapat memberikan kenyamanan dan membuat suasana belajar yang menyenangkan selama proses pembelajaran agar siswa termotivasi belajar dan tidak berpandangan matematika itu sulit, menakutkan, dan membosankan lagi.

Berhasil atau tidaknya kegiatan belajar mengajar matematika di sekolah dapat diukur dari hasil belajar siswa dan hasil belajar tersebut sangat bergantung pada proses pembelajaran di dalam kelas.

Sebelum pelaksanaan proses pembelajaran di kelas dilakukan, seorang guru terlebih dahulu harus menata, mengorganisasikan proses pembelajaran yang akan diajarkan. Hal ini perlu dilakukan agar isi pembelajaran yang diajarkan mudah dipahami siswa karena kesulitan belajar matematika tidak 
Mutia, M. (2016). PENERAPAN PEMBELAJARAN KOOPERATIF TEAM ACCELERATED INSTRUCTION (TAI) UNTUK MENINGKATKAN MOTIVASI DAN HASIL BELAJAR SISWA.JURNAL TATSQIF, 14(2). Retrieved from http://ejurnal.iainmataram.ac.id/index.php/tatsqif/article/view/1023

hanya disebabkan sulitnya materi pelajaran matematika, tetapi juga disebabkan kurang efektifnya metode penyampaian guru dalam mengelola pembelajaran matematika sehingga membuat siswa merasa bosan terhadap apa yang disampaikan guru di dalam kelas. Guru lebih aktif memberikan informasi kepada siswa, sedangkan siswa bersikap pasif. Dengan kata lain pembelajaran terpusat pada guru (Lie, 2010). Sedangkan berdasarkan observasi yang telah dilakukan, cara pengajaran yang dilaksanakan di SMP Negeri 14 Kota Bengkulu masih menggunakan model pembelajaran konvensional oleh guru matematika dimana guru banyak menjelaskan materi di depan kelas menggunakan papan tulis dan siswa mendengarkan. Akibatnya pada saat kegiatan belajar mengajar berlangsung kebanyakan siswa masih sibuk dengan teman sebangkunya atau mengganggu siswa yang lain yang ingin belajar sehingga membuat suasana kelas menjadi tidak teratur. Tidak hanya itu, terkadang siswa yang merasa kemampuannya kurang juga merasa minder untuk belajar karena tingkat kemampuan yang dimilikinya tidak sama dengan kemampuan tinggi yang bisa menerima pelajaran dengan cepat. Untuk menghadapi persoalan tersebut, guru diharapkan dapat mengubah strategi pembelajaran, guru harus dapat menyajikan materi pelajaran dan kondisi pembelajaran yang menarik minat belajar siswa. Jika selama ini pembelajaran hanya didominasi oleh guru maka sebaiknya guru dapat menciptakan suasana belajar dimana siswa juga dapat berpartisipasi secara optimal dan mampu berkompetisi secara sehat dengan temannya. Salah satu model pembelajaran yang dapat digunakan agar siswa dapat berperan aktif dan mengembangkan sikap toleransi serta saling membantu adalah model pembelajaran kooperatif yaitu diantaranya pembelajaran kooperatif tipe Team Accelerated Instruction (TAI).

Dalam menerapkan model pembelajaran kooperatif tipe Team Accelerated Instruction (TAI) ini, siswa tidak hanya menerapkan pembelajaran kooperatif tapi juga pembelajaran secara individual secara bersamaan. Kalau selama ini kooperatif dipandang sebagai model 
Mutia, M. (2016). PENERAPAN PEMBELAJARAN KOOPERATIF TEAM ACCELERATED INSTRUCTION (TAI) UNTUK MENINGKATKAN MOTIVASI DAN HASIL BELAJAR SISWA.JURNAL TATSQIF, 14(2). Retrieved from http://ejurnal.iainmataram.ac.id/index.php/tatsqif/article/view/1023

pembelajaran dimana siswa banyak bergantung pada kelompoknya, tidak demikian dengan Team Accelerated Instruction (TAI). Model pembelajaran kooperatif ini mengkombinasikan pembelajaran individu dan kelompok. Kombinasi pengajaran berpusat pada siswa dan kerja secara kelompok akan membuat siswa menjadi lebih kreatif, saling membantu dalam mencari pemecahan masalah yang diberikan oleh guru dan dituntut untuk aktif dalam mengikuti setiap kegiatan dalam pembelajaran. Pembelajaran TAI memotivasi siswa untuk membantu anggota kelompoknya sehingga tercipta semangat dalam sistem kompetisi dengan sedikit menonjolkan peran individu tanpa mengorbankan aspek kooperatif. Dalam pembelajaran TAI, pendidik hanya berperan sebagai fasilitator dan mediator dalam proses pembelajaran.

Berdasarkan uraian di atas peneliti ingin mengembangkan suatu tindakan yang dapat meningkatkan motivasi dan hasil belajar matematika dalam proses pembelajaran matematika melalui Penerapan Model Pembelajaran Kooperatif Tipe Team Accelerated Instruction (TAI).

Bertitik tolak dari latar belakang di atas, rumusan masalah dalam penelitian ini adalah "Bagaimana penerapan model pembelajaran kooperatif tipe Team Accelerated Instruction (TAI) dalam pembelajaran matematika untuk meningkatkan memotivasi dan hasil belajar siswa?".

Adapun tujuan penelitian ini adalah untuk mengetahui bagaimana cara menerapkan model pembelajaran kooperatif tipe Team Accelerated Instruction (TAI) dalam pembelajaran matematika sehingga dapat memotivasi siswa dalam belajar dan dapat meningkatkan hasil belajar siswa.

\section{LANDASAN TEORI}

Pembelajaran matematika adalah kegiatan pendidikan yang menggunakan matematika sebagai kendaraan untuk mencapai tujuan yang ditetapkan. Matematika sebagai wahana pendidikan tidak hanya dapat digunakan untuk mencapai satu tujuan, misalnya mencerdaskan siswa, tetapi 
Mutia, M. (2016). PENERAPAN PEMBELAJARAN KOOPERATIF TEAM ACCELERATED INSTRUCTION (TAI) UNTUK MENINGKATKAN MOTIVASI DAN HASIL BELAJAR SISWA.JURNAL TATSQIF, 14(2). Retrieved from http://ejurnal.iainmataram.ac.id/index.php/tatsqif/article/view/1023

dapat pula untuk membentuk kepribadian siswa serta mengembangkan keterampilan tertentu. Hal ini mengarah perhatian kepada pembelajaran nilai-nilai dalam kehidupan melalui matematika (Soedjadi, 2000).

Matematika pada umumnya diajarkan pada setiap jenjang pendidikan yaitu Sekolah Dasar (SD), Sekolah Menengah Pertama (SMP), Sekolah Menengah Tingkat Atas (SMA/SMK), dan Perguruan Tinggi (PT). Namun, pembelajaran matematika pada setiap jenjang pendidikan memiliki karakteristik yang berbeda-beda. Pembelajaran matematika di sekolah perlu memperhatikan aspek teori psikologi khususnya teori psikologi perkembangan. Anak didik memerlukan tahapan belajar sesuai dengan perkembangan jiwa dan kognitifnya. Potensi yang ada pada diri anak pun berkembang dari tingkat rendah ke tingkat tinggi, dari sederhana ke kompleks. Berdasarkan hal tersebut, maka jelaslah karakteristik pembelajaran metematika tidak dapat begitu saja diterapkan tanpa menyesuaikan dengan perkembangan anak didik.

Pengetahuan dibentuk oleh individu dengan proses belajar yang harus disesuaikan dengan tahap perkembangan intelektual (kognitif) yang dilalui siswa. Dalam hal ini, Piaget membaginya menjadi empat tahap, yaitu (i) tahap sensori-motor (0;0-2;0 tahun); (ii) tahap praoperasional (2;0-7;0 tahun); (iii) tahap operasional konkret (7;0-11;0 tahun); (iv) tahap operasional formal (11;0 tahun ke atas) (Piaget, 1999).

Dilihat dari tahapan perkembangan kognitif yang dikemukakan Piaget tersebut, siswa SMP secara teoritis berada pada bagian akhir periode operasional konkret dan awal periode operasional formal. Pada usia ini, siswa mulai mengalami perkembangan dalam kemampuan berpikir secara simbolis dan mulai dapat memahami sesuatu secara bermakna tanpa memerlukan objek yang konkret atau bahkan objek yang visual dan anak mulai dapat berpikir logis tentang berbagai gagasan yang abstrak. Tapi, bukan berarti anak tidak membutuhkan objek konkret dalam proses pembelajaran, benda-benda konkret yang sederhana yang ada di sekitar 
Mutia, M. (2016). PENERAPAN PEMBELAJARAN KOOPERATIF TEAM ACCELERATED INSTRUCTION (TAI) UNTUK MENINGKATKAN MOTIVASI DAN HASIL BELAJAR SISWA.JURNAL TATSQIF, 14(2). Retrieved from http://ejurnal.iainmataram.ac.id/index.php/tatsqif/article/view/1023

lingkungan anak dapat dijadikan media belajar untuk mempermudah dan menarik motivasi belajar anak.

Implikasinya dalam pembelajaran matematika adalah perlunya disiapkan rancangan pengajaran matematika yang memfasilitasi perkembangan kemampuan berpikir siswa. Upaya yang dapat dilakukan yaitu dengan menerapkan suatu pendekatan pembelajaran yang melibatkan tutor sebaya dan penggunaan benda-benda konkret yang dapat digunakan untuk meningkatkan motivasi belajar siswa sehingga diharapkan sesuai dengan karakteristik dari siswa SMP.

Model pembelajaran kooperatif merupakan salah satu model pembelajaran yang dapat diterapkan dalam pembelajaran matematika di SMP. Siswa yang belajar dalam tingkat menengah pertama sangat memerlukan bimbingan teman sebayanya dalam menerima dan memahami pelajaran karena tingkat kemampuan siswa SMP masih dalam tahap operasional-konkret menuju ke tahap operasi formal dimana dalam memecahkan masalah masih mengalami kegagalan. Tidak semua siswa mampu menerima pelajaran dengan cepat. Begitu juga dalam menyelesaikan tugas-tugas, siswa ada yang merasa minder karena kemampuannya tidak sama dengan siswa yang kemampuannya tinggi sehingga membuat dia semakin tidak mengerti dengan apa yang harus ia kerjakan. Dengan pembelajaran kooperatif, siswa dapat bekerja sama dan saling membantu siswa yang sulit menerima pelajaran, siswa dapat belajar secara langsung dengan teman sebayanya, karena dengan melalui bahasa teman siswa mungkin lebih memahami materi yang dipelajari. Demikian juga saat penyelesaian tugas-tugas dari guru, siswa yang kemampuannya kurang dapat belajar dari siswa yang kemampuannya lebih dalam satu kelompok.

Pembelajaran kooperatif adalah pembelajaran yang di dalamnya mengkondisikan para siswa untuk bekerja bersama-sama di dalam kelompok-kelompok kecil untuk saling membantu satu sama lain dalam belajar (Djamarah, 2010). 
Mutia, M. (2016). PENERAPAN PEMBELAJARAN KOOPERATIF TEAM ACCELERATED INSTRUCTION (TAI) UNTUK MENINGKATKAN MOTIVASI DAN HASIL BELAJAR SISWA.JURNAL TATSQIF, 14(2). Retrieved from http://ejurnal.iainmataram.ac.id/index.php/tatsqif/article/view/1023

Dalam pembelajaran kooperatif terdapat unsur keaktifan, konstruktivis, dan kooperatif (Djamarah, 2010). Belajar aktif ditunjukkan dengan adanya keterlibatan siswa dalam berdiskusi dengan kelompoknya dalam memahami materi dan menyelesaikan tugas bersama yang diberikan guru, siswa dapat mengemukakan pendapat dan idenya secara bebas. Konstruktivistik dalam pembelajaran kooperatif dapat terlihat dari diskusi dan percobaan. Siswa menafsirkan bersama-sama apa yang mereka pelajari dan mereka bahas. Materi pelajaran dibangun secara bersama dan bukan sebagai transfer dari guru. Pengetahuan dibentuk berdasarkan pengalaman serta interaksinya dengan lingkungan dalam kelompok belajar. Dengan demikian siswa didorong untuk membangun pengetahuannya secara bersama-sama di dalam kelompok. Sementara itu, kooperatif itu sendiri mampu memberikan kesempatan kepada siswa untuk berkomunikasi dan menyampaikan ideidenya.

Model pembelajaran cooperative learning tidak sama dengan sekedar belajar dalam kelompok. Ada unsur-unsur dasar pembelajaran cooperative learning yang membedakannya dengan pembagian kelompok yang dilakukan asal-asalan. Pelaksanaan prosedur model cooperative learning dengan benar akan memungkinkan pendidik mengelola kelas dengan lebih efektif (Lie, 2010).

Melalui pembelajaran kooperatif, siswa tidak hanya belajar dan menerima apa yang disajikan oleh guru dalam PBM, melainkan juga bisa belajar dari siswa lainnya, dan sekaligus mempunyai kesempatan untuk membelajarkan siswa yang lain. Guru bukan lagi berperan sebagai satusatunya nara sumber dalam PBM, tetapi berperan sebagai mediator, stabilisator, dan manajer pembelajaran. Iklim belajar yang berlangsung dalam suasana keterbukaan dan demokratis akan memberikan kesempatan yang optimal bagi siswa untuk memperoleh informasi yang lebih banyak mengenai materi yang dibelajarkan dan sekaligus melatih sikap dan keterampilan sosialnya sebagai bekal dalam kehidupannya di masyarakat, 
Mutia, M. (2016). PENERAPAN PEMBELAJARAN KOOPERATIF TEAM ACCELERATED INSTRUCTION (TAI) UNTUK MENINGKATKAN MOTIVASI DAN HASIL BELAJAR SISWA.JURNAL TATSQIF, 14(2). Retrieved from http://ejurnal.iainmataram.ac.id/index.php/tatsqif/article/view/1023

sehingga perolehan dan hasil belajar siswa akan semakin meningkat (Djamarah, 2010).

Tidak ada satu model pembelajaran pun yang paling baik di antara model pembelajaran yang lain. Demikian halnya dengan model pembelajaran kooperatif. Ada sejumlah keunggulan dan kelemahan yang dimilikinya. Salah satu kelemahan model pembelajaran kooperatif yaitu pembelajaran kooperatif dapat membuat siswa yang lemah cenderung minder terhadap siswa yang pandai (Djamarah, 2010). Hal ini tentu membuat guru berhatihati memilih tipe model pembelajaran kooperatif. Team Accelerated Instruction (TAI) merupakan salah satu tipe model pembelajaran kooperatif yang dapat diterapkan dalam proses pembelajaran untuk mengatasi masalah tersebut sebab pembelajaran menggunakan tipe TAI sangat mengutamakan kemampuan siswa yang heterogen dalam satu kelas. Siswa yang pandai diharapkan dapat membantu belajar siswa yang kemampuannya kurang. Sehingga tidak perlu adanya lagi sikap minder yang cenderung terjadi. Begitu juga dalam mengatasi kelemahan siswa yang menyalin pekerjaan siswa yang pandai. Di dalam TAI ini juga, pembelajaran secara individu diterapkan sehingga adanya kombinasi pembelajaran individual dan kelompok.

Pembelajaran kooperatif tipe Team Accelerated Instruction (TAI) ini dikembangkan oleh Robert E. Slavin. TAI sama dengan STAD dan TGT menggunakan penggunaan bauran kemampuan empat anggota yang berbeda dan memberi sertifikat untuk tim dengan kinerja terbaik. Namun, metode STAD dan TGT menggunakan pola pengajaran tunggal untuk satu kelas sementara TAI menggabungkan pembelajaran kooperatif dengan pengajaran yang individual yang dirancang untuk mengatasi kesulitan belajar siswa secara individual. Selain itu, STAD dan TGT dapat diaplikasi pada hampir semua mata pelajaran dan tingkat kelas, sementara TAI dirancang khusus untuk mengajarkan matematika kepada siswa.

TAI memiliki berbagai dinamika motivasi dari STAD dan TGT. Para siswa saling mendukung dan saling membantu satu sama lain untuk 
Mutia, M. (2016). PENERAPAN PEMBELAJARAN KOOPERATIF TEAM ACCELERATED INSTRUCTION (TAI) UNTUK MENINGKATKAN MOTIVASI DAN HASIL BELAJAR SISWA.JURNAL TATSQIF, 14(2). Retrieved from http://ejurnal.iainmataram.ac.id/index.php/tatsqif/article/view/1023

berusaha keras karena mereka semua menginginkan tim mereka berhasil. Tanggung jawab individu bisa dipastikan hadir karena satu-satunya skor yang diperhitungkan adalah skor akhir dan siswa melakukan tes akhir tanpa bantuan teman satu tim (Slavin, 2010).

Dalam TAI, para siswa memasuki sekuen individual berdasarkan tes penempatan dan kemudian melanjutkannya dengan tingkat kemampuan mereka sendiri. Secara umum, anggota kelompok bekerja pada unit pelajaran yang berbeda. Teman satu tim saling memeriksa hasil kerja masing-masing menggunakan lembar jawaban dan saling membantu dalam menyelesaikan berbagai masalah. Unit tes yang terakhir akan dilakukan tanpa bantuan teman atau tim dan skornya dihitung dengan monitor siswa. Tiap minggu, guru menjumlahkan angka dari tiap unit yang telah diselesaikan semua anggota tim dan memberikan sertifikat atau penghargaan tim lainnya untuk tim yang berhasil melampaui kriteria skor yang didasarkan pada angka tes terakhir yang telah dilakukan, dengan poin ekstra untuk lembar jawaban yang sempurna dan pekerjaan rumah yang telah diselesaikan (Slavin, 2010).

Pembelajaran menggunakan model pembelajaran kooperatif TAI ini dapat memberikan keunggulan tersendiri dalam proses pembelajaran, seperti yang dikemukakan oleh Slavin dalam bukunya bahwa TAI dirancang untuk memberikan kepuasan kriteria berikut dalam menyelesaikan masalahmasalah dari sistem pengajaran individual:

1. Dapat meminimalisir keterlibatan guru dalam pemeriksaan dan pengelolaan rutin;

2. Guru setidaknya akan menghabiskan separuh dari waktunya untuk mengajar kelompok-kelompok kecil;

3. Tersedianya banyak cara pengecekan penguasaan supaya para siswa jarang menghabiskan waktu mempelajari kembali materi yang sudah mereka kuasai atau menghadapi kesulitan serius yang membutuhkan bantuan guru; 
4. Para siswa akan dapat melakukan pengecekan satu sama lain, sekalipun bila siswa yang mengecek kemampuannya ada di bawah siswa yang dicek dalam rangkaian pengajaran, dan prosedur pengecekan akan cukup sederhana dan tidak mengganggu si pengecek;

5. Dengan membuat para siswa bekerja dalam kelompok-kelompok kooperatif, dengan status yang sejajar, program ini akan membangun kondisi untuk terbentuknya sikap-sikap positif terhadap siswa-siswa yang berasal dari latar belakang yang berbeda (Slavin, 2010).

Dalam TAI terdapat komponen-komponen pembelajaran yang berbeda dengan kooperatif tipe lainnya seperti STAD dan TGT, komponen-komponen TAI tersebut antara lain terdiri dari :

\section{Teams}

Para siswa dalam TAI dibagi ke dalam tim-tim yang beranggotakan 4 sampai 5 orang.

\section{Tes Penempatan (Placement Test)}

Siswa diberi placement test pada permulaan untuk ditempatkan pada tingkat yang sesuai dalam program individual berdasarkan hasil tes dan nilai semester peserta didik pada bidang tertentu.

\section{Materi-materi Kurikulum (Curriculum Materials)}

Guru menyiapkan materi-materi kurikulum individual dalam kelompok kecil. Tiap unit mempunyai bagian-bagian sebagai berikut: a) halaman panduan yang mengulang konsep-konsep yang telah diperkenalkan oleh guru dalam kelompok pengajaran; b) beberapa halaman untuk latihan kemampuan. Tiap latihan kemampuan memperkenalkan subkemampuan yang mengarah pada penguasaan akhir dari seluruh kemampuan; c) tes formatif; d) tes Keseluruhan/tes unit; e) halaman jawaban untuk halaman latihan kemampuan dan tes formatif.

\section{Kelompok Pengajaran (Teaching Group)}

Guru memberikan materi secara singkat untuk mengenalkan konsepkonsep utama kepada para siswa. Pelajaran tersebut dirancang untuk 
membantu para siswa memahami hubungan antara pelajaran matematika yang mereka kerjakan dengan soal-soal yang sering ditemui dan juga merupakan soal-soal dalam kehidupan nyata. Secara umum, para siswa tersebut menerima pengenalan konsep-konsepnya dalam pengajaran sebelum mereka mengerjakan soal-soal tersebut dalam unit-unit individual. Sementara guru bekerja bersama kelompok pengajaran, siswasiswa lainnya melanjutkan pengerjaan unit-unit individual mereka dalam timnya masing-masing.

\section{Belajar Kelompok (Team Study)}

Siswa mengerjakan unit matematika individual dengan membentuk kelompok untuk melakukan pengecekan pekerjaan individual anggota lain. Siswa mengerjakan soal dengan bantuan tim sebelum meminta bantuan kepada guru. Tiap siswa mengerjakan dua soal pertama dalam latihan kemampuannya sendiri dan selanjutnya jawabannya dicek oleh teman satu timnya dengan halaman jawaban yang sudah tersedia, yang dicetak dengan urutan terbalik di dalam buku. Apabila kedua soal tersebut benar, siswa tersebut boleh melanjutkan ke latihan kemampuan berikutnya. Jika ada yang salah, mereka harus mencoba mengerjakan kembali kedua soal tersebut, dan seterusnya sampai siswa bersangkutan dapat menyelesaikan kedua soal tersebut dengan benar. Para siswa yang menghadapi masalah pada tahap ini didorong untuk meminta bantuan dari timnya sebelum meminta bantuan dari guru. Pada tes formatif para siswa ditandatangani oleh siswa pemeriksa yang berasal dari tim lain supaya bisa mendapatkan tes unit yang sesuai. Siswa tersebut selanjutnya menyelesaikan tes unitnya, dan siswa pemeriksa akan menghitung skornya.

\section{Skor Tim dan Rekognisi Tim (Team Score and team recognition)}

Pada tiap akhir siklus, guru menghitung jumlah skor tim. Skor ini didasarkan pada jumlah rata-rata unit yang bisa dicakupi oleh tiap anggota tim dan jumlah tes-tes unit yang berhasil diselesaikan dengan 
Mutia, M. (2016). PENERAPAN PEMBELAJARAN KOOPERATIF TEAM ACCELERATED INSTRUCTION (TAI) UNTUK MENINGKATKAN MOTIVASI DAN HASIL BELAJAR SISWA.JURNAL TATSQIF, 14(2). Retrieved from http://ejurnal.iainmataram.ac.id/index.php/tatsqif/article/view/1023

akurat. Kriteria yang tinggi ditetapkan bagi sebuah tim untuk menjadi Tim Super, Kriteria Sedang untuk menjadi Tim Sangat Baik, dan kriteria minimum untuk menjadi Tim Baik.

7. Unit Seluruh Kelas (Whole-Class Unit)

Guru memberikan materi kepada seluruh siswa pada akhir pembelajaran sebagai refleksi (Slavin, 2010).

Langkah-langkah pelaksanaan Pembelajaran Kooperatif Tipe TAI ini dapat dirangkum dalam tabel berikut :

Tabel 1

Langkah Pembelajaran Kooperatif Tipe TAI

\section{Langkah 1 : Placement Test (Tes Penempatan)}

Kegiatan yang dilakukan :

Memberikan placement test kepada siswa.

\section{Langkah 2 : Teams (Pembagian Kelompok)}

Kegiatan yang dilakukan :

Membentuk kelompok-kelompok kecil yang heterogen tapi harmonis berdasarkan nilai placement test dan nilai ulangan sebelumnya. Setiap kelompok beranggotakan 4-5 orang.

\section{Langkah 3 : Teaching Group (Kelompok Pengajaran)}

Kegiatan yang dilakukan :

Guru memberikan materi secara singkat selama 10-15 menit pada pelajaran pertama untuk mengenalkan konsep-konsep utama kepada para siswa dan setiap kegiatan pembelajaran berkelompok di kelas, guru memberikan pengajaran ke beberapa kelompok untuk membantu belajar siswa bila diperlukan.

\section{Langkah 4 : Team Study (Belajar Kelompok)}

Kegiatan yang dilakukan :

Setiap kelompok siswa mendapatkan materi-materi kurikulum individual yang berbeda untuk setiap anggota kelompoknya berdasarkan hasil tes penempatan. Materi-materi kurikulum tersebut berisikan halaman panduan mengenai konsep-konsep yang telah diperkenalkan oleh guru dan soal-soal latihan kemampuan serta tes formatif.

1. Para siswa membaca halaman panduan mereka dan meminta teman satu tim atau guru membantu bila diperlukan.

2. Memulai mengerjakan latihan kemampuan yang pertama dalam unit mereka.

3. Tiap siswa mengerjakan beberapa soal pertama dalam latihan kemampuannya sendiri dan selanjutnya jawabannya dicek oleh teman satu timnya dengan halaman jawaban yang sudah tersedia. Apabila soalsoal tersebut benar dijawab, siswa boleh melanjutkan ke latihan 
Mutia, M. (2016). PENERAPAN PEMBELAJARAN KOOPERATIF TEAM ACCELERATED INSTRUCTION (TAI) UNTUK MENINGKATKAN MOTIVASI DAN HASIL BELAJAR SISWA.JURNAL TATSQIF, 14(2). Retrieved from http://ejurnal.iainmataram.ac.id/index.php/tatsqif/article/view/1023

kemampuan berikutnya. Jika ada yang salah, mereka harus mencoba mengerjakan kembali soal-soal tersebut dan seterusnya sampai siswa tersebut dapat menyelesaikan soal-soal tersebut dengan benar.

4. Apabila sudah mengerjakan latihan kemampuan terakhir, siswa dapat mengerjakan tes formatif yang mirip dengan latihan kemampuan. Apabila siswa tersebut dapat mengerjakan soal-soal dengan benar, teman dari tim lain yang memiliki tingkat soal yang sama akan memeriksa jawaban tes dan menandatangani hasil tes itu untuk menunjukkan bahwa sistem tersebut dinyatakan sah oleh temannya untuk mengikuti tes keseluruhan.

5. Jika siswa belum bisa mengerjakan soal tes formatif, maka siswa diminta kembali untuk mengerjakan soal-soal latihan kemampuan. Aturan dalam belajar matematika menggunakan TAI : siswa dengan kemampuan tinggi yang mendapat soal dengan tingkat kesulitan yang tinggi dikoreksi oleh siswa dari anggota kelompok lain yang memiliki tingkat kemampuan yang tinggi berdasarkan hasil tes penempatan di permulaan pembelajaran. Begitu juga dengan tingkat kemampuan sedang dan rendah.

6. Siswa mengerjakan tes unit/keseluruhan secara individu untuk melihat penguasaan materi dari proses pembelajaran yang telah dilakukan.

\section{Langkah 5 : Whole-Class Unit (Unit Seluruh Kelas)}

Kegiatan yang dilakukan :

Guru mengecek pemahaman siswa tentang materi pembelajaran dan membahas materi yang kurang dipahami siswa menjelang akhir pembelajaran.

Langkah 6 : Team Score and Recognition (Skor Tim dan Rekognisi Tim)

Kegiatan yang dilakukan :

Guru menetapkan kelompok terbaik sampai kelompok yang kurang berhasil (jika ada) berdasarkan hasil koreksi di akhir siklus (Azmi, 2009; Slavin, 2010).

\section{METODE}

Jenis penelitian yang dilaksanakan adalah penelitian tindakan kelas (PTK). Penelitian Tindakan Kelas adalah penelitian yang dilakukan oleh guru, bekerja sama dengan peneliti (atau dilakukan oleh guru sendiri yang juga bertindak sebagai peneliti) di kelas atau di sekolah tempat ia mengajar dengan penekanan pada penyempurnaan atau peningkatan proses dan praktis pembelajaran (Arikunto dan Suhardjono, 2010). 
Penelitian ini dilakukan selama tiga siklus yang masing-masing melalui empat tahap berikut: 1) perencanaan (Planning); 2) pelaksanaan Tindakan (Acting); 3) pengamatan (Observing); dan 4) refleksi (Reflecting).

Penelitian Tindakan Kelas ini dilaksanakan di kelas VIII-3 SMP Negeri 14 Kota Bengkulu dengan jumlah siswa sebanyak 37 orang terdiri dari 17 lakilaki dan 20 perempuan. Latar belakang siswa yang dibutuhkan dalam penelitian ini juga adalah siswa dengan motivasi belajar yang masih cukup rendah.

Instrumen penelitian yang digunakan untuk mengumpulkan data dalam penelitian ini adalah :

\section{Lembar Angket}

Dalam penelitian tindakan kelas ini, angket digunakan untuk mengukur tingkat motivasi belajar siswa.

Angket yang akan diisi oleh siswa berhubungan dengan sikap siswa selama proses pembelajaran matematika berlangsung melalui penerapan pembelajaran kooperatif tipe Team Accelerated Instruction (TAI). Siswa diminta memilih beberapa kriteria yang telah disediakan, yaitu: sangat setuju (SS), setuju (S), Ragu-ragu (RR), tidak setuju (TS), sangat tidak setuju (STS). Kemudian skor setiap item pertanyaan angket dijumlahkan dan akan digolongkan dalam interval.

Kisaran nilai tiap kriteria $=\frac{\text { Skor tertinggi keseluruhan }- \text { skor terendah }}{\text { Skor tertinggi tiap butir observasi }}$

Kemudian persentase siswa yang memiliki respon positif dan negatif dihitung dengan:

$$
\text { Persentase respon }=\frac{\sum \text { Siswa yang memiliki respon }}{\sum \text { Siswa }} \times 100 \%
$$

2. Lembar Observasi Aktivitas Siswa;

Dalam penelitian ini, observasi yang dilakukan merupakan observasi langsung yang sistematis yaitu dengan mengisi lembar observasi siswa 
yang bertujuan untuk mengamati keaktifan siswa dalam upaya peningkatan motivasi belajar siswa pada saat pembelajaran melalui penerapan pembelajaran kooperatif tipe Team Accelerated Instruction (TAI). Observasi langsung merupakan cara mengumpulkan data penilaian yang dilakukan melalui pengamatan dan pencatatan gejala-gejala yang tampak pada objek evaluasi pada saat peristiwa, keadaan, situasi sedang berlangsung (Zamzaili, 2001).

Lembar observasi dapat berupa daftar periksa / check list atau skala penilaian (rating scale). Daftar periksa berupa daftar pertanyaan atau pernyataan yang jawabannya tinggal memberi check (centang) pada jawaban yang sesuai dengan aspek yang diamati dan dianalisa dengan pilihan jawaban: Baik (B), Cukup (C), Kurang (K).

Penentuan kisaran dan nilai untuk tiap kriteria pengamatan dhitung dengan:

Skor tertinggi $=$ Jumlah butir observasi $\mathrm{x}$ skor tertinggi tiap butir soal observasi.

Dalam pengamatan/observasi penelitian ini, peneliti akan menggunakan 2 (dua) orang pengamat (observer). Hasil pengamatan yang akan diperoleh dari 2 (dua) orang pengamat ini akan dirata-ratakan dan dihitung kesamaan aspek yang diamati. Untuk menentukan toleransi perbedaan hasil pengamatan digunakan teknik pengetesan reliabilitas pengamatan yang dirumuskan dengan :

$$
\mathrm{KK}=\frac{2 \mathrm{~S}}{\mathrm{~N}_{1}+N_{2}}
$$

Ket $:$ KK $=$ koefisien kesepakatan

$\mathrm{S} \quad$ = sepakat, jumlah kode yang sama untuk objek yang sama

$\mathrm{N}_{1}$ = jumlah kode yang dibuat oleh pengamat 1

$\mathrm{N}_{2}$ = jumlah kode yang dibuat oleh pengamat 2 (Arikunto, 1996) 
3. Lembar Tes Hasil Belajar.

Tes hasil belajar adalah sekelompok pertanyaan atau tugas-tugas yang harus dijawab atau diselesaikan oleh siswa dengan tujuan untuk mengukur kemajuan belajar siswa (Slameto, 1994).

Tes yang digunakan dalam penelitian ini terdiri dari placement test (pre-test), latihan kemampuan, tes formatif, dan tes unit/keseluruhan (post-test). Nilai akhir individu diperoleh dengan jalan menjumlahkan nilai skor awal/placement test (A), tes formatif (F), tes unit/keseluruhan (U), dan ditambah dengan poin ekstra dari penghargaan masing-masing kelompok yang masing-masing diberi bobot 15\% untuk skor awal, $25 \%$ untuk tes formatif, 50\% untuk tes unit, dan 10\% untuk poin ekstra, Jika dituangkan dalam bentuk rumus:

$$
\mathrm{N}_{\mathrm{A}}=15 \%(A)+25 \%(F)+50 \%(U)+10 \%(\text { poin ekstra })
$$

\section{Poin Ekstra dalam kelompok :}

10 poin untuk untuk Tim Super

5 Poin untuk Tim Sangat Baik

0 Poin untuk Tim Baik

Sedangkan nilai rata-rata hasil belajar secara klasikal siswa dihitung dengan menggunakan rumus:

$$
\bar{X}=\frac{\sum X}{N}
$$

Ket: $\bar{X}=$ nilai rata-rata siswa

$\sum X=$ jumlah nilai semua siswa

$N=$ jumlah siswa

dan persentase ketuntasan belajar secara klasikal dihitung dengan: 


$$
\mathrm{KB}=\frac{n^{\prime}}{n} \times 100 \%
$$

Ket: $\mathrm{KB}=$ ketuntasan belajar

$n^{\prime}=$ jumlah siswa yang memperoleh nilai $\geq \mathrm{KKM}$

$n$ = jumlah peserta tes (Purwanto, 2009)

\section{HASIL DAN PEMBAHASAN}

Sebelum dilaksanakannya tindakan kelas pembelajaran melalui model pembelajaran kooperatif tipe Team Accelerated Instruction (TAI) pada pokok bahasan Kubus dan Balok di kelas VIII-3 SMP Negeri 14 Kota Bengkulu, terlebih dahulu peneliti melakukan observasi awal ke kelas.

Setelah observasi awal ini dilakukan, peneliti selanjutnya melakukan tes penempatan (placement test) dengan materi prasyarat persegi, persegi panjang, teorema Pythagoras, dan pengkuadratan. Tes ini dilakukan untuk melihat pengetahuan awal siswa serta kemampuan masing-masing siswa untuk dapat ditempatkan ke dalam kelompok-kelompok belajar tipe kooperatif TAI sesuai dengan kemampuannya.

Tabel 2

Hasil Tes Penempatan

\begin{tabular}{|lll|}
\hline Hasil Tes Penempatan & $\begin{array}{l}\text { Nilai yang } \\
\text { Diperoleh }\end{array}$ & $\begin{array}{l}\text { Indikator } \\
\text { Keberhasilan }\end{array}$ \\
\hline $\begin{array}{l}\text { Nilai Rata-Rata } \\
\begin{array}{l}\text { Persentase } \quad \text { Keberhasilan } \\
\text { Belajar }\end{array}\end{array}$ & $\begin{array}{l}47,02 \\
8,11 \%\end{array}$ & $\begin{array}{l}65,00 \\
80 \%\end{array}$ \\
\hline Kriteria & & \\
\hline
\end{tabular}

Dari tabel diketahui bahwa nilai rata-rata yang diperoleh belum memenuhi indikator keberhasilan belajar yang telah ditetapkan, yaitu 65,00. Begitu pula dengan persentase keberhasilan belajar belum mencapai $80 \%$. Dengan demikian dapat diketahui bahwa kesiapan belajar dan motivasi belajar siswa masih sangat kurang. Hal ini mendorong upaya penggunaan 
Mutia, M. (2016). PENERAPAN PEMBELAJARAN KOOPERATIF TEAM ACCELERATED INSTRUCTION (TAI) UNTUK MENINGKATKAN MOTIVASI DAN HASIL BELAJAR SISWA.JURNAL TATSQIF, 14(2). Retrieved from http://ejurnal.iainmataram.ac.id/index.php/tatsqif/article/view/1023

tindakan pembelajaran yang tepat. Untuk itu, peneliti mencoba melaksanakan proses pembelajaran dengan menerapkan model pembelajaran kooperatif tipe Team Accelerated Instruction (TAI) untuk meningkatkan motivasi dan hasil belajar siswa kelas VIII-3 SMP Negeri 14 Kota Bengkulu.

\section{Siklus I}

Pada siklus I, model pembelajaran kooperatif tipe Team Accelerated Instruction (TAI) mulai diterapkan dengan mengacu pada perencanaan yang telah dibuat yaitu: 1) mempersiapkan perangkat pembelajaran, materi yang diajarkan pada siklus I adalah kubus dan balok dengan sub pokok bahasan unsur-unsur kubus dan balok; dan 2) menyiapkan nama-nama kelompok dalam belajar. Selanjutnya, pada tahap tindakan guru melakukan kegiatan pendahuluan, kegiatan inti sesuai dengan sintaks pembelajaran TAI, dan penutup.

Pengamatan dilakukan pada saat proses belajar mengajar sedang berlangsung. Dalam pengamatan aktivitas siswa, hasil yang dianalisis tidak hanya dilihat dari satu pengamat, tetapi juga dilihat dari pengamat 2 yang kemudian dirata-ratakan sehingga memperoleh skor rata-rata. Selain itu, dalam mengamati aktivitas siswa dalam belajar, pengamat 1 dan 2 perlu berdiskusi dulu agar hasil pengamatan yang diperoleh mencapai persamaan apersepsi dari semua pengamat. Dari penyamaan apersepsi tersebut, maka toleransi perbedaan hasil pengamatan siklus I dapat dilihat dari perhitungan reliabilitas pengamatan.

Tabel 3

Hasil Observasi Keaktifan Siswa pada Siklus I

\begin{tabular}{|l|l|l|l|}
\hline \multicolumn{2}{|c|}{ Pengamat } & \multicolumn{1}{c|}{$\begin{array}{c}\text { Rata-Rata Skor } \\
\text { (Kategori) }\end{array}$} & $\begin{array}{c}\text { Indikator } \\
\text { Keberhasilan }\end{array}$ \\
\cline { 1 - 2 } I & II & 15 (Kurang) & Kategori Baik \\
\hline Kriteria & 14 & Belum Berhasil \\
\hline
\end{tabular}

Dari tabel di atas diketahui bahwa rata-rata skor pada hasil observasi dua pengamat berada pada kriteria kurang dengan skor 15 dan belum mencapai 
Mutia, M. (2016). PENERAPAN PEMBELAJARAN KOOPERATIF TEAM ACCELERATED INSTRUCTION (TAI) UNTUK MENINGKATKAN MOTIVASI DAN HASIL BELAJAR SISWA.JURNAL TATSQIF, 14(2). Retrieved from http://ejurnal.iainmataram.ac.id/index.php/tatsqif/article/view/1023

kriteria baik. Oleh karena itu, perlu adanya upaya peningkatan pelaksanaan pembelajaran untuk siklus berikutnya melalui tindakan-tindakan yang lebih tepat lagi.

Dalam pelaksanaan tindakan kelas dengan penerapan model pembelajaran kooperatif TAI ini, nilai akhir siklus I tidak hanya diperoleh dari nilai tes unit/keseluruhan seutuhnya, melainkan diperoleh dengan jalan menjumlahkan nilai skor awal/tes penempatan (A), tes formatif (F), tes unit/keseluruhan (U), dan ditambah dengan poin ekstra dari penghargaan masing-masing kelompok yang masing-masing diberi bobot 15\% untuk skor awal, 25\% untuk tes formatif, 50\% untuk tes unit, dan 10\% untuk poin ekstra.

Berdasarkan analisis nilai akhir siklus I tersebut, diperoleh data sebagai berikut :

Tabel 4

Hasil Belajar Siswa Siklus I

\begin{tabular}{|llll|}
\hline Nilai Akhir Siklus I & $\begin{array}{l}\text { Nilai } \\
\text { Diperoleh }\end{array}$ & yang & $\begin{array}{l}\text { Indikator } \\
\text { Keberhasilan }\end{array}$ \\
\hline $\begin{array}{l}\text { Nilai Rata-Rata } \\
\begin{array}{l}\text { Persentase } \\
\text { Belajar }\end{array}\end{array}$ & 56,44 & 65,00 \\
Kriteria & $27,02 \%$ & $80 \%$ \\
\hline
\end{tabular}

Dari tabel di atas diketahui bahwa nilai rata-rata yang diperoleh belum mencapai $80 \%$. Maka, perlu adanya upaya peningkatan hasil belajar pada siklus berikutnya.

Dalam pelaksanaan siklus I ini, penerapan model pembelajaran kooperatif TAI dalam tindakan siklus I masih belum dapat dilaksanakan dengan baik. Ada komponen-komponen yang belum dapat diterapkan dalam pelaksanaan pembelajaran di kelas yaitu kegiatan pengoreksian latihan kemampuan oleh sesama anggota kelompok dalam komponen team study dan kegiatan whole class unit. Pengoreksian latihan kemampuan oleh teman sekelompok belum dapat dilakukan, karena guru belum mampu mengatur alokasi waktu yang 
Mutia, M. (2016). PENERAPAN PEMBELAJARAN KOOPERATIF TEAM ACCELERATED INSTRUCTION (TAI) UNTUK MENINGKATKAN MOTIVASI DAN HASIL BELAJAR SISWA.JURNAL TATSQIF, 14(2). Retrieved from http://ejurnal.iainmataram.ac.id/index.php/tatsqif/article/view/1023

baik dalam pembelajaran. Pembelajaran kelas (whole class unit) pun belum terlaksana untuk mengecek pemahaman siswa dan membahas latihan kemampuan yang dikerjakan secara individu dalam kelompoknya. Tidak terlaksananya komponen ini dalam pembelajaran karena belum mampu mengalokasikan waktu sebaik mungkin untuk dapat melakukan kegiatan tersebut. Untuk memperbaiki tindakan tersebut, guru melakukan perencanaan dengan alokasi waktu yang lebih baik lagi di siklus II.

\section{Siklus II}

Siklus II ini merupakan upaya perbaikan terhadap tindakan yang belum terlaksana pada siklus I dengan tahapan yang sama. Dengan perencanaan yang lebih baik dan memberikan alternatif pemecahan masalah dari masalah yang ditemukan dari siklus I diharapkan dapat memberikan hasil yang lebih baik. Materi yang disampaikan pada siklus ini adalah jaring-jaring kubus dan balok serta luas permukaannya.

Hasil observasi pada siklus II yang dirangkum oleh 2 (dua) orang pengamat dengan menggunakan lembar observasi ditunjukkan oleh tabel berikut :

Tabel 5

Hasil Observasi Keaktifan Siswa pada Siklus II

\begin{tabular}{|c|c|c|c|}
\hline \multicolumn{2}{|c|}{ Pengamat } & $\begin{array}{c}\text { Rata-Rata Skor } \\
\text { (Kategori) }\end{array}$ & $\begin{array}{c}\text { Indikator } \\
\text { Keberhasilan }\end{array}$ \\
\hline 23 & II & 22,5 (Cukup) & Kategori Baik \\
\hline Kriteria & 22 & Belum Berhasil \\
\hline
\end{tabular}

Dari tabel di atas diketahui bahwa rata-rata skor pada hasil observasi dua pengamat masih berada pada kriteria cukup dengan skor 22,5 dan belum mencapai kriteria baik. Oleh karena itu, perlu adanya upaya peningkatan pelaksanaan pembelajaran yang lebih baik untuk siklus berikutnya. 
Tabel 6

Hasil Belajar Siklus II

\begin{tabular}{|lcc|}
\hline \multicolumn{1}{|c|}{ Nilai Akhir Siklus II } & $\begin{array}{l}\text { Nilai yang } \\
\text { Diperoleh }\end{array}$ & $\begin{array}{l}\text { Indikator } \\
\text { Keberhasilan }\end{array}$ \\
\hline Nilai Rata-Rata & 72,22 & 65,00 \\
Persentase Keberhasilan Belajar & $67,57 \%$ & $80 \%$ \\
\hline Kriteria & Belum Berhasil \\
\hline
\end{tabular}

Dari tabel di atas diketahui bahwa nilai rata-rata yang diperoleh sudah lebih baik dari nilai rata-rata yang diperoleh pada siklus I dan telah memenuhi indikator keberhasilan belajar yang telah ditetapkan. Namun demikian, persentase keberhasilan belajar yang diperoleh belum mencapai indikator keberhasilan 80\%, yang diperoleh hanya sebesar 67,57\% (25 siswa). Hal ini mendorong upaya peningkatan hasil belajar untuk siklus berikutnya.

Dalam siklus II ini, semua komponen TAI sudah terlaksana semua, namun, dalam kegiatan team study, siswa belum menunjukkan kooperatifnya dalam belajar, siswa masih cenderung individu. Tindakan yang dilakukan guru untuk mengatasi hal tersebut adalah dengan memberikan pengarahan kepada siswa bahwa nilai individu juga dipengaruhi oleh nilai kelompok. Nilai setiap anggota kelompoknya mendapat tambahan skor 10.

\section{Siklus III}

Siklus III ini merupakan upaya perbaikan peneliti terhadap tindakan yang belum terlaksana pada siklus II dan peningkatan terhadap tindakan yang telah tercapai. Dengan perencanaan yang lebih baik dan memberikan alternatif pemecahan masalah dari masalah yang ditemukan dari siklus II diharapkan hasil belajar yang diperoleh dapat mencapai kriteria yang telah ditetapkan dan terjadinya peningkatan motivasi belajar siswa terhadap pembelajaran matematika.

Pengamatan (observasi) masih dilakukan oleh peneliti sendiri dengan bantuan 2 orang pengamat. Hasil observasi pada siklus III tersebut ditunjukkan oleh tabel berikut: 
Mutia, M. (2016). PENERAPAN PEMBELAJARAN KOOPERATIF TEAM ACCELERATED INSTRUCTION (TAI) UNTUK MENINGKATKAN MOTIVASI DAN HASIL BELAJAR SISWA.JURNAL TATSQIF, 14(2). Retrieved from http://ejurnal.iainmataram.ac.id/index.php/tatsqif/article/view/1023

Tabel 7

Hasil Observasi Keaktifan Siswa pada Siklus III

\begin{tabular}{|l|c|c|c|}
\hline \multicolumn{2}{|l|}{ Pengamat } & $\begin{array}{c}\text { Rata-Rata } \\
\text { Skor } \\
\text { (Kategori) }\end{array}$ & $\begin{array}{c}\text { Indikator } \\
\text { Keberhasilan }\end{array}$ \\
\hline 28 & II & 27 (Baik) & Kategori Baik \\
\hline Kriteria & 26 & Berhasil & \\
\hline
\end{tabular}

Dari tabel di atas diketahui bahwa rata-rata skor pada hasil observasi dua pengamat sudah berada pada kriteria baik dengan skor 27 artinya siswa sudah aktif dalam melaksanakan kegiatan pembelajaran melalui penerapan model pembelajaran kooperatif TAI.

Tabel 8

Hasil Belajar Siswa Siklus III

\begin{tabular}{|llcl|}
\hline Nilai Akhir Siklus III & $\begin{array}{l}\text { Nilai } \\
\text { Diperoleh }\end{array}$ & yang & $\begin{array}{l}\text { Indikator } \\
\text { Keberhasilan }\end{array}$ \\
\hline $\begin{array}{l}\text { Nilai Rata-Rata } \\
\begin{array}{l}\text { Persentase } \\
\text { Belajar }\end{array}\end{array}$ & $\begin{array}{l}84,79 \\
\text { Keberhasilan }\end{array}$ & $91,89 \%$ & 65,00 \\
Kriteria & & $80 \%$ \\
\hline
\end{tabular}

Dari tabel di atas diketahui bahwa nilai rata-rata yang diperoleh telah mencapai indikator keberhasilan belajar yaitu 84,79 dengan persentase keberhasilan belajar sebesar 91,89\% (34 siswa) dari 80\% yang ditargetkan.

Pada siklus III ini, pelaksanaan komponen TAI dalam kegiatan pembelajaran sudah semakin baik. Hal ini dapat dilihat dari pencapaian yang diperoleh saat refleksi pelaksanaan siklus III. Peningkatan ini terjadi karena guru selalu berupaya merefleksi dan memperbaiki hal-hal yang masih belum terlaksana dengan baik pada siklus sebelumnya seperti membuat LKS kelompok yang berbeda dengan LKS individu sebelumnya. LKS kelompok ini dibuat untuk meningkatkan interaksi dan sikap kooperatif siswa dalam berkelompok.

Dalam pembelajaran kooperatif ini ada 3 predikat untuk hasil kelompok yaitu: tim baik, sangat baik, dan super. Untuk kelompok yang mendapat 
Mutia, M. (2016). PENERAPAN PEMBELAJARAN KOOPERATIF TEAM ACCELERATED INSTRUCTION (TAI) UNTUK MENINGKATKAN MOTIVASI DAN HASIL BELAJAR SISWA.JURNAL TATSQIF, 14(2). Retrieved from http://ejurnal.iainmataram.ac.id/index.php/tatsqif/article/view/1023

predikat tim super akan mendapatkan poin ekstra 10 (10\% dari 100), tim sangat baik mendapat poin ekstra 5 (10\% dari 50), dan tim baik mendapat poin ekstra 0. Dengan adanya pemberian poin ekstra ini, diharapkan siswa dapat memberikan yang terbaik dalam kelompoknya.

\section{Motivasi Belajar Siswa}

Peningkatan motivasi belajar siswa pada penelitian ini dilakukan dengan menerapkan model pembelajaran kooperatif TAI. Peningkatan motivasi belajar siswa dapat dilihat dari angket dan observasi siswa.

Persentase siswa yang memiliki sikap positif terhadap pembelajaran melalui penerapan kooperatif TAI pada siklus I, II, dan III dapat dilihat pada tabel berikut :

Tabel 9

Persentase Motivasi Siswa terhadap Pembelajaran kooperatif TAI

\begin{tabular}{|cccc|}
\hline No. & Siklus & Sikap Positif (\%) & Sikap Negatif (\%) \\
\hline 1. & Siklus I & $78,38 \%$ & $21,62 \%$ \\
2. & Siklus II & $83,78 \%$ & $16,22 \%$ \\
3. & Siklus III & $94,59 \%$ & $5,41 \%$ \\
\hline
\end{tabular}

Dari tabel di atas dapat dilihat bahwa setiap siklus terjadi peningkatan motivasi siswa terhadap pembelajaran kooperatif TAI artinya siswa semakin menyukai belajar kooperatif tipe TAI dan semakin termotivasi dalam belajar.

\section{Keaktifan Siswa}

Pengamatan aktivitas oleh observer selalu mengalami peningkatan dari setiap siklus. Artinya, aktivitas belajar siswa dari siklus ke siklus semakin baik. Peningkatan aktivitas ini terjadi karena guru selalu melakukan peningkatan terhadap motivasi belajar siswa. Secara grafis keaktifan siswa pada siklus I, siklus II, dan siklus III dapat ditunjukkan pada grafik di bawah ini : 


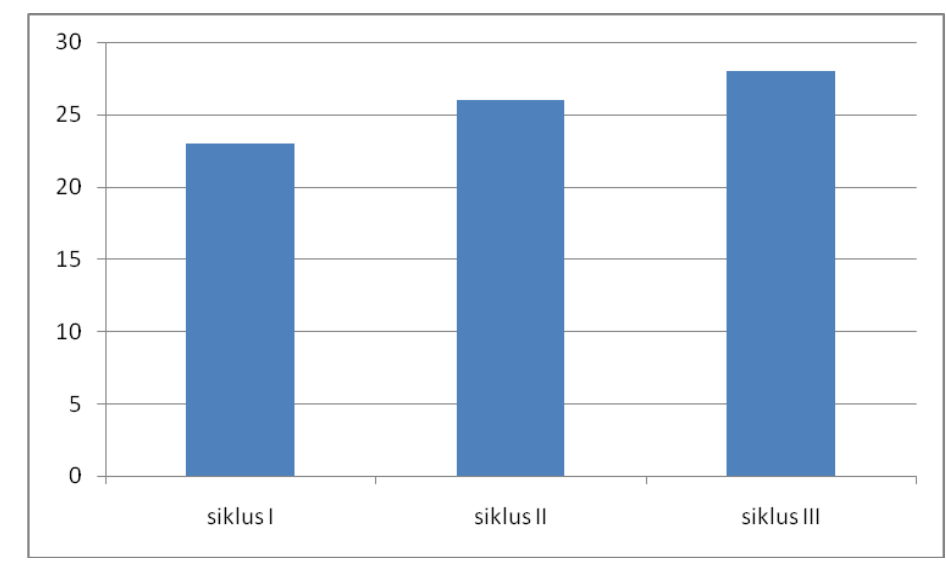

Gambar 1

Diagram Keaktifan Siswa

Dengan demikian dapat ditunjukkan bahwa motivasi belajar siswa dapat dilihat dalam aktivitas siswa, dengan meningkatnya aktivitas siswa dalam proses pembelajaran, maka motivasi belajar siswa juga semakin tinggi.

Dalam siklus I, keaktifan yang dilakukan oleh siswa belum menunjukkan tingkat motivasi yang tinggi dari siswa, keaktifan siswa melalui pembelajaran kooperatif Team Accelerated Instruction masih berada pada kriteria kurang dengan skor 15 dan belum mencapai kriteria baik.

Pada siklus II. Aktivitas siswa yang tidak diharapkan dalam siklus I tidak banyak lagi dilakukan di siklus II karena guru selalu berupaya meningkatkan motivasi belajar siswa agar aktivitas siswa semakin baik dalam proses pembelajaran TAI. Siswa sudah terbiasa dengan model pembelajaran kooperatif TAI. Siswa sudah mulai mendengarkan penjelasan dari guru saat penyampaian materi karena guru selalu menggunakan alat peraga dalam penjelasannya. Di samping aktivitas yang semakin baik ditunjukkan oleh siswa, namun masih ditemukan beberapa aktivitas siswa yang belum sesuai harapan yaitu saat kegiatan berkelompok dilakukan, siswa mulai ribut kembali dan mengganggu ketenteraman kelas. Sebagian siswa juga masih ada yang belum membaca materi-materi LKS, sehingga masih ditemukan siswa yang masih membutuhkan bimbingan guru.

Pada siklus III, keaktifan yang ditunjukkan sudah berada pada kriteria baik. Siswa sudah mulai memahami cara belajar kooperatif TAI, sebelum 
Mutia, M. (2016). PENERAPAN PEMBELAJARAN KOOPERATIF TEAM ACCELERATED INSTRUCTION (TAI) UNTUK MENINGKATKAN MOTIVASI DAN HASIL BELAJAR SISWA.JURNAL TATSQIF, 14(2). Retrieved from http://ejurnal.iainmataram.ac.id/index.php/tatsqif/article/view/1023

mengerjakan latihan kemampuan 1 dan 2, siswa membaca materi-materi kurikulum terlebih dahulu dan siswa yang ribut di kelas sudah mulai berkurang.

\section{Hasil Belajar Siswa}

Nilai rata-rata siswa mengalami peningkatan setiap siklus. Pada siklus I, nilai rata-rata siswa yang diperoleh sebesar 56,44 dengan ketuntasan belajar secara klasikal 27,02\%. Pada siklus II, terjadi peningkatan pada nilai ratarata yaitu rata-ratanya menjadi 72,22 dan persentase keberhasilan sebesar 67,57\%. Perbaikan yang dilakukan peneliti dalam siklus II hingga mengalami peningkatan adalah selalu berupaya memperbaiki tindakan yang sudah terlaksana tapi belum berhasil. Hasil belajar pada siklus III mengalami peningkatan kembali dari siklus II, rata-rata belajar mencapai 84,79 dan persentase ketuntasan belajar klasikal adalah 91,89\%. Berdasarkan kriteria ketuntasan belajar secara klasikal yang ditetapkan yaitu $\leq 80 \%$ dari jumlah siswa, maka pada siklus III kriteria hasil belajar tercapai. Untuk lebih jelasnya, peningkatan hasil belajar siswa dapat digambarkan pada grafik rata-rata hasil belajar siswa berikut :

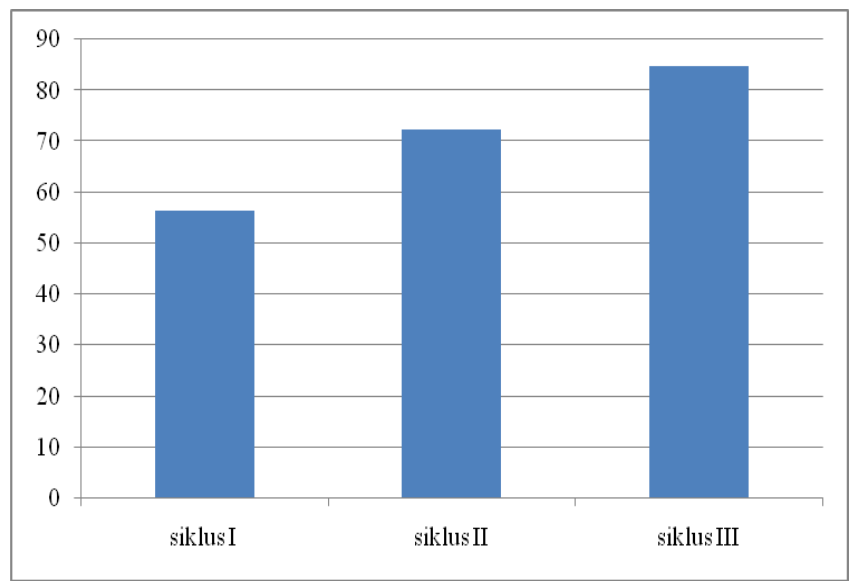

Gambar 2

Diagram Rata-rata Hasil Belajar Siswa 
Mutia, M. (2016). PENERAPAN PEMBELAJARAN KOOPERATIF TEAM ACCELERATED INSTRUCTION (TAI) UNTUK MENINGKATKAN MOTIVASI DAN HASIL BELAJAR SISWA.JURNAL TATSQIF, 14(2). Retrieved from http://ejurnal.iainmataram.ac.id/index.php/tatsqif/article/view/1023

\section{KESIMPULAN}

Berdasarkan penelitian yang telah dilaksanakan di kelas VIII-3 SMP Negeri 14 Kota Bengkulu, maka disimpulkan bahwa penerapan pembelajaran kooperatif tipe Team Accelerated Instruction (TAI) dalam pembelajaran matematika dapat meningkatkan motivasi siswa dengan cara: 1)penggunaan alat peraga dalam pembelajaran dengan melibatkan siswa aktif dalam mendemonstrasikan alat peraga; 2) guru menyusun LKS lengkap dengan ringkasan materi dan latihan kemampuannya. Selain LKS individu juga membuat LKS kelompok; 3) membuat soal dengan tingkat soal yang berbedabeda sehingga siswa termotivasi untuk meningkatkan hasil belajarnya dan dapat mengerjakan soal dengan tingkat yang lebih tinggi; 4) guru membentuk kelompok baru di setiap awal siklus pembelajaran yang didasarkan atas nilai akhir yang diperoleh di setiap siklus; 5) guru memberikan hadiah dan penghargaan untuk kelompok super dengan poin ekstra 10 yang kemudian diakumulasikan dengan nilai individu lainnya; 6) guru memberikan bimbingan secara intensif ke kelompok-kelompok yang anggotanya mengalami kesulitan dalam mengerjakan soal latihan. Tingkat motivasi siswa dari siklus I hingga siklus III mengalami peningkatan. Ini ditunjukkan dari analisis angket siswa dan diikuti dengan aktivitas siswa.

Penerapan pembelajaran kooperatif tipe Team Accelerated Instruction (TAI) dalam pembelajaran matematika dapat meningkatkan hasil belajar matematika dengan cara : 1) meningkatkan motivasi belajar siswa agar aktivitas siswa juga meningkat. Dari motivasi yang semakin baik, hasil belajar yang diharapkan juga baik ; 2) menyusun LKS belajar siswa baik individu maupun kelompok yang dilengkapi dengan ringkasan materi dan latihan kemampuan siswa; 3) melakukan pengoreksian latihan, dengan adanya pengoreksian secara bersama, siswa dapat belajar dari kesalahan dan tidak terulang lagi pada tes selanjutnya; 4)melakukan pembelajaran unit kelas (whole class unit) dengan membahas soal-soal yang masih salah dan sulit dikerjakan siswa. 


\section{DAFTAR PUSTAKA}

Arikunto, Suharsimi. (1996). Prosedur Penelitian : Suatu Pendekatan Praktek. Jakarta: Rineka Cipta.

Arikunto, Suharsimi dan Suhardjono. (2010). Penelitian Tindakan Kelas. Jakarta: Bumi Aksara.

Azmi, Desmiati. (2010). Perbedaan Hasil Belajar Matematika Siswa Antara Model Pembelajaran Kooperatif Tipe TAI (Team Accelerated Instruction) dan Student Team Achievement Division (STAD) di kelas VII SMP N 18 Kota Bengkulu. Skripsi. Universitas Bengkulu.

Dimyati dan Mudjiono. (1999). Belajar dan Pembelajaran. Jakarta: Rineka Cipta.

Djamarah, Syaiful Bahri. (2010). Guru dan Anak Didik Dalam Interaksi Edukatif. Jakarta: Rineka Cipta.

Hamalik, Oemar. (2009). Proses Belajar Mengajar. Bandung: Bumi Aksara.

Lie, Anita. (2010). Mempraktekkan Cooperative Learning di Ruang-ruang Kelas. Jakarta: Gramedia.

Purwanto, Andik. (2009). Penerapan Media Jejaring Sosial “Facebook" Pada Matakuliah Termodinamika. Jurnal Exacta, 7(2) 2009.

Slameto. (1994). Evaluasi Pendidikan. Jakarta: Bina Aksara.

Slavin, Robert. (2010). Cooperative Learning : theory, research, and practice. Terjemahan Narulita Yusron. London: Allymand Bacon.

Soedjadi, R. (2000). Kiat Pendidikan Matematika di Indonesia. Jakarta: Depdiknas.

Sudijono, Anas. (2005). Pengantar Evaluasi Pendidikan. Jakarta: Raja Grafindo Persada.

Sugiyono. (2008). Metode Penelitian Kuantitatif, kualitatif, dan R\&D. Bandung: Alfabeta.

Zamzaili. (2001). Buku Ajar :Evaluasi Proses dan Hasil Pembelajaran Matematika. Bengkulu: Universitas Bengkulu. 